\title{
Kajian Awal Kemunculan Hiu Paus (Rhyncodon typus, Smith 1828) di Teluk Tomini Dihubungkan dengan Faktor Fisik dan Biologi Perairan
}

\author{
Preliminary Study of Whale Sharks Occurance (Rhyncodon typus, Smith 1828) \\ in Gulf of Tomini Connected with \\ Physical and Biological Factors of Water
}

\author{
Arip Rahman, Joni Haryadi, Agus Arifin Sentosa, Mujiyanto \\ Balai Penelitian Pemulihan dan Konservasi Sumberdaya Ikan \\ e-mail: alphagrt79@gmail.com
}

\begin{abstract}
Abstrak
Kemunculan hiu paus di Desa Botubarani Teluk Tomini Gorontalo menjadi fenomena langka bagi masyarakat setempat. Kegiatan pengamatan kemunculan hiu paus (Rhincodon typus) dilakukan pada bulan April dan Mei 2016 di Teluk Tomini Gorontalo. Metode penelitian yang digunakan adalah pengamatan bawah air untuk mengidentifikasi hiu paus dan tingkah lakunya. Pengukuran kualitas air dan pengambilan sampel plankton dan larva dilakukan disekitar lokasi kemunculan hiu paus. Selama pengamatan ditemukan lima ekor hiu paus dengan ukuran berkisar 3-8 m. Tingkah laku hiu paus yang teramati oleh penyelam, hiu paus muncul dari kedalaman $>100 \mathrm{~m}$ kemudian berenang berputar-putar pada kedalaman 15-20 m sesekali membuka mulutnya untuk menyaring makanan. Hasil pengamatan kualitas air disekitar lokasi kemunculan hiu paus, nilai salinitas berkisar antara 31,96-33,23\% $\%$, nilai oksigen terlarut berkisar 6,02-7,48 mg. $\mathrm{l}^{-1}$. Kelimpahan zooplankton tertinggi diperoleh pada pengamatan bulan April yaitu Acartia sp. dari kelas Crustaceae dengan kelimpahan 12385 ind. $1^{-1}$. Kelimpahan larva disekitar lokasi kemunculan hiu paus didominasi oleh copepod dan larva ikan. Faktor makanan diduga menjadi salah satu faktor munculnya hiu paus di Teluk Tomini.
\end{abstract}

Kata kunci : Hiu paus, Teluk Tomini, Plankton, Larva

\begin{abstract}
The occurrence of whale shark in Botubarani village the gulf of Tomini Gorontalo became a rare phenomenon for the local community. Observation of appearance of whale shark (Rhincodon typus) was conducted in April and May 2016 in the Gulf of Tomini Gorontalo. The method used is an underwater observation to identify the whale sharks and its behavior. Measurements of water quality and take sample of plankton and larva around the location of the whale shark appears. During the observation founded five whale sharks with sizes ranging from 3 to $8 \mathrm{~m}$. Divers observed that whale shark appears from $>100 \mathrm{~m}$ depth and then circles at $15-20 \mathrm{~m}$ depth and occasionally opening its mouth to filter food. The result of water quality measurement around the location of whale sharks, salinity 31,96-33,23\% $\%$, dissolved oxygen 6,02-7,48 mg. $\mathrm{l}^{-1}$. The highest abundance of zooplankton was observed in April from Crustaceae (Acartia sp.) 12385 ind.1-1. Copepod and fish larvae are dominated around the location of whale shark appear. The abundance of foods is suspected of whale sharks appearance at Gulf of Tomini.
\end{abstract}

Keywords : Whale sharks, Gulf of Tomini, Plankton, Larva 


\section{Pendahuluan}

Hiu paus (Rhincodon typus) merupakan salah satu dari tiga spesies paus yang kebiasaan makannya dilakukan dengan cara menghisap dan menyaring (filter feeder) (Compagno, 1984), dua spesies lainnya adalah Basking Shark (Cetorhinus maximus) dan Megamouth Shark (Megachasma pelagios). International Union for Conservation of Nature (IUCN), memasukan hiu paus ini ke dalam daftar merah untuk spesies yang terancam dengan status rentan (vulnerable) karena populasinya diduga terus mengalami penurunan. Sementara itu, Convention on International Trade in Endengered Species(CITES) memasukkan hiu paus dalam Apendiks II yang artinya perdagangan untuk hiu paus ini harus melalui aturan yang menjamin pemanfaatanya tidak akan mengancam kelestariannya. Sejak tahun 2013, Pemerintah Indonesia telah mengeluarkan Keputusan Menteri Kelautan dan Perikanan Republik Indonesia Nomor 18/Kepmen-KP/2013 yang menetapkan perlindungan penuh terhadap hiu paus ini.

Hiu paus memiliki habitat pelagis yang berarti bahwa hiu paus lebih banyak menghabiskan waktu di permukaan atau kolom perairan (Colman, 2007), tetapi sering juga dijumpai di perairan lepas hingga perairan pantai, bahkan kadang masuk ke daerah laguna. Secara umum distribusi dan kelimpahan hiu paus dipengaruhi oleh proses oseanografi seperti peristiwa umbalan, arus pantai dan daerah pertemuan arus, dimana terjadi peningkatan produktivitas disekitar lingkungan tersebut (Wilson et al., 2001; Duffy, 2002). Meskipun memiliki daerah distribusi yang luas, namun terdapat beberapa lokasi dimana hiu paus tersebut bisa diprediksi kemunculannya berdasarkan pengamatan dalam waktu yang lama. Prediksi lokasi kemunculan hiu paus tersebut biasanya berdasarkan kelimpahan plankton (de la Parra-Venegas et al., 2011). Beberapa lokasi yang bisa diprediksi tentang kemunculan hiu paus diantaranya Ningaloo Reef (Australia)
(Taylor, 1994), Belize (Heyman et al., 2001) dan Seychelles (Rowat dan Gore, 2007).

Di perairan Indonesia hiu paus sering dijumpai di lokasi dekat pantai atau muaramuara sungai. Hal ini diduga berkaitan dengan kelimpahan makanan seperti nutrien (zooplankton dan phytoplankton) dan kelompok ikan-ikan kecil di sekitar perairan tersebut sehingga daerah perairan tersebut juga disebut sebagai feeding ground. Beberapa lokasi kemunculan hiu paus di perairan Indonesia antara lain: perairan Derawan - Kalimantan Timur; Kepulauan Spermonde - Sulawesi Selatan, perairan pantai Kenjeran-Jawa Timur dan di beberapa lokasi lainnya pada periode berbeda. Hasil studi hiu paus di wilayah Taman Nasional Teluk Cendrawasih menunjukkan bahwa hiu paus sering muncul di sekitar bagan karena tertarik dengan sekumpulan ikan yang terperangkap dalam bagan (Tania, 2014).

Fenomena kemunculan kelompok hiu paus di perairan sekitar Botubarani Gorontalo diduga bukan untuk tujuan migrasi sementara tetapi karena didukung kondisi lingkungan dan keterdiaan makanan. Menurut Stewart (2012) salah satu faktor kelompok hiu paus muncul di suatu perairan karena tertarik adanya konsentrasi ikan-ikan pelagis. Pengamatan di lokasi kemunculan hiu paus dilakukan untuk menduga faktor-faktor yang menyebabkan munculnya hiu paus di lokasi tersebut baik faktor fisik maupun biologi perairan. Hasil penelitian diharapkan dapat memberikan informasi awal mengenai faktor yang mempengaruhi kemunculan hiu paus di Teluk Tomini.

\section{Bahan dan Metode}

Penelitian dilakukan dengan menggunakan metode survey langsung di lokasi kemunculan hiu paus disekitar perairan di Desa Botubarani, Kecamatan Kabila Bone, Kabupaten Bone Bolango, Gorontalo (Gambar 1). Survey lapangan dilakukan sebanyak dua kali yaitu pada bulan April dan Mei 2016. 


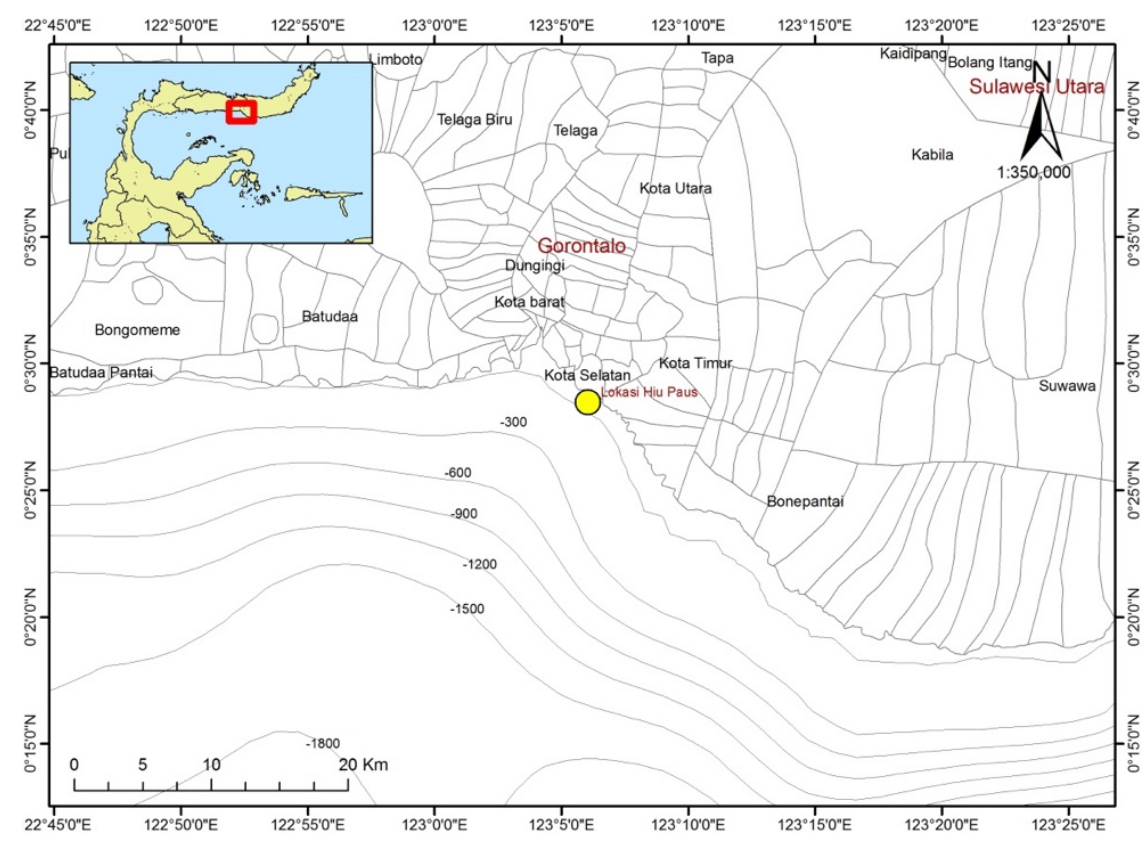

Gambar 1. Peta lokasi survey kemunculan hiu paus

Figure 1. Map of survey location whale shark occurrence

Pengamatan hiu paus dan kondisi lingkungan disekitarnya dilakukan dengan metode Photo Id untuk monitoring hiu paus yang dikeluarkan oleh Direktorat Konservasi Kawasan dan Jenis Ikan Ditjen Kelautan, Pesisir dan Pulau-Pulau Kecil Kementerian Kelautan dan Perikanan. Tiga orang penyelam dengan membawa kamera bawah air melakukan penyelaman bebas untuk melakukan pengamatan terhadap hiu paus dan lingkungan disekitarnya. Jenis informasi yang diperoleh melalui Metode Photo Id diantaranya adalah identitas hiu paus (Photo Id) dan karakteristik hiu paus yang teridentifikasi yang berupa ukuran, jenis kelamin dan tanda khusus lainnya. Pengukuran beberapa parameter kualitas air dilakukan secara insitu dengan menggunakan Water Quality Checker (WQC) yang waktu pengukurannya bersamaan dengan pengamatan bawah air. Parameter kualitas air yang diukur antara lain: suhu, salinitas, $\mathrm{pH}$, oksigen terlarut. Pengambilan sampel plankton dilakukan dengan menggunakan plankton net dengan ukuran mata jaring 300 $\mu \mathrm{m}$ dan diameter bukaan mulutnya $30 \mathrm{~cm}$. Pengambilan sampel plankton dilakukan di permukaan air dengan cara menarik plankton net dengan jarak $10 \mathrm{~m}$. Sampel plankton kemudian diawetkan dengan formalin (4\%) dan dianalisi di laboratorium dengan menggunakan buku identifikasi Yamaji (1979). Penentuan kelimpahan plankton menggunakan metode Lackey drop microtransect counting (APHA, 2005) dengan persamaan sebagai berikut:

$$
N=n \times \frac{A}{B} \times \frac{C}{D} \times \frac{1}{E}
$$

Keterangan :

$N \quad=$ Jumlah total plankton $\left(\right.$ sel. $^{-1}$, ind $^{-1}$ )

$n \quad=$ Jumlah rataan total individu per

lapang pandang

$A \quad=$ Luas gelap penutup $\left(\mathrm{mm}^{2}\right)$

$B \quad=$ Luas lapang pandang $\left(\mathrm{mm}^{2}\right)$

C $=$ Volume air terkonsentrasi $(\mathrm{ml})$

$\mathrm{D} \quad=$ Volume air satu tetes $(\mathrm{ml})$ dibawah gelas penutup

$\mathrm{E} \quad=$ Volume air yang disaring (1)

Pengambilan sampel larva dilakukan dengan menggunakan bongo net dengan ukuran mata jaring $600 \mu \mathrm{m}$ dengan diameter bukaan mulut jaring $50 \mathrm{~cm}$. Bongo net ditarik dengan menggunakan perahu dengan kecepatan rata-rata sekitar 2 knot selama 10 menit. Sampel yang diperoleh kemudian diawetkan dengan menggunkan formalin dan 
dibawa ke laboratorium untuk dianalisis. Kelimpahan meroplankton (larva) dihitung dengan menggunakan rumus dari SEAFDEC (2006), yaitu :

$$
N=\frac{n}{V t s r}
$$

Keterangan:

$\mathrm{N}$ = Kelimpahan larva (ind $/ 1000 \mathrm{~m}^{3}$ )

$\mathrm{n}=$ Jumlah larva yang tercacah (ind)

$\mathrm{v}_{\mathrm{tsr}}=$ Volume air tersaring $(\mathrm{Vtsr}=1 \times \mathrm{t} \times \mathrm{v})$

dimana,

1 : Luas bukaan mulut saringan

t : lama waktu penarikan saringan (menit), 10 menit

$\mathrm{v}$ : Kecepatan tarikan (m/menit), 10 menit dengan kecepatan rata-rata 2 knot

\section{Hasil dan Pembahasan}

\section{Hasil}

Hasil pengamatan ditemukan lima ekor hiu paus dengan ukuran berkisar antara 3-8 $\mathrm{m}$ yang muncul pada saat diberi makan limbah kepala udang dari atas perahu. Pengamatan jenis kelamin hiu paus dilakukan pada saat penyelaman dengan mengamati lubang genital dari individu hiu paus tersebut. Tiga dari lima ekor hiu paus yang ditemukan teridentifikasi berjenis kelamin jantan yang ditandai dengan adanya klasfer (Gambar 2). Sedangkan dua ekor hiu paus yang lain tidak dapat diidentifikasi karena terbatasnya jarak pandang dan posisi pengamat dan posisi hiu paus yang kurang tepat
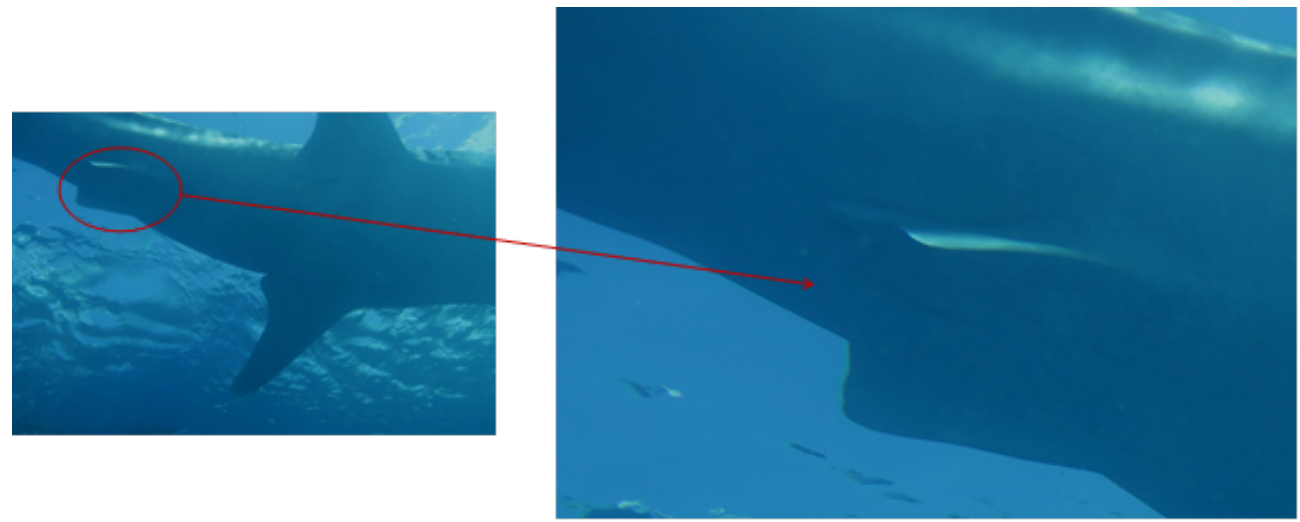

Gambar 2. Identifikasi jenis kelamin hiu paus (jantan, terdapat klasfer)

Figure 2. Identification of sex of whale shark (male, with clasper)

Gambaran tingkah laku hiu paus yang teramati oleh penyelam disajikan pada Gambar 3. Hiu paus datang dari kedalaman $>$ $100 \mathrm{~m}$ kemudian berenang berputar putar pada kedalaman 15-20 m dan sesekali membuka mulutnya untuk menyaring makanan. Kemudian berenang menuju permukaan mendekati perahu yang menebarkan kepala dan cangkang udang. Hiu paus menghisap sisa kepala udang dan cangkang udang dengan posisi vertikal, kemudian hiu paus berenang kembali menuju perairan yang lebih dalam dan menghilang di kedalaman $>100 \mathrm{~m}$. 


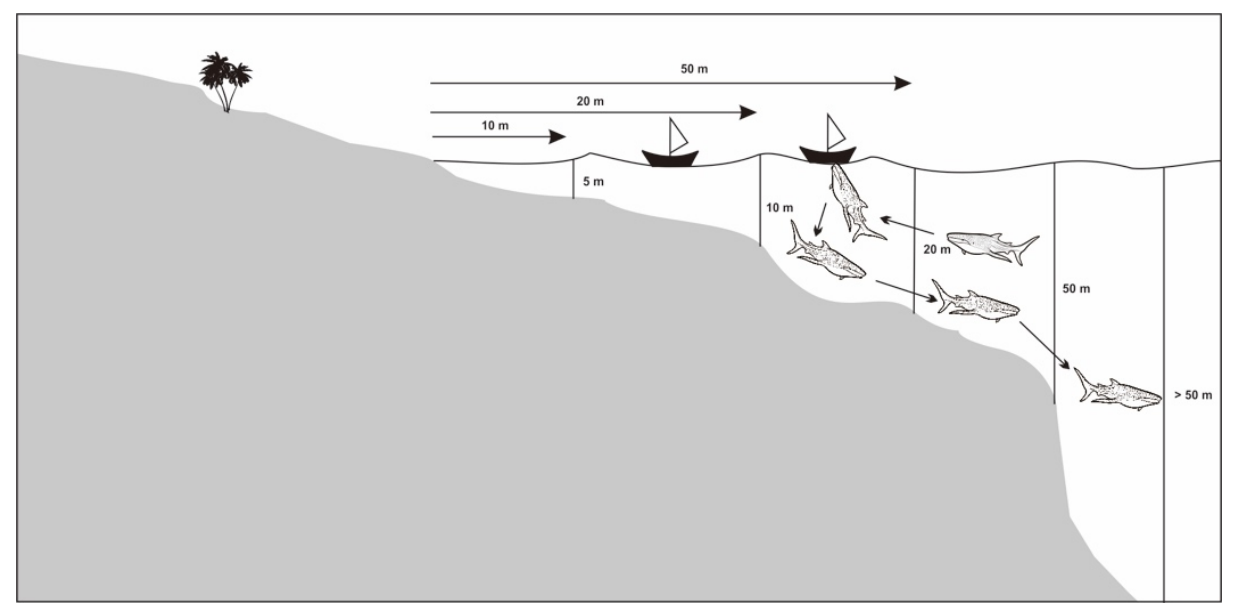

Gambar 3. Gambaran tingkah laku hiu paus pada saat penyelaman

Figure 3. Picture of the behavior of whale sharks during the dive

Pengukuran kualitas air di sekitar lokasi kemunculan hiu paus dilakukan sebagai data pendukung untuk menggambarkan kondisi perairan disekitarnya. Pengukuran dan pengambilan sampel air dilakukan pada tiga kedalaman (Permukaan, $4 \mathrm{~m}$ dan $8 \mathrm{~m}$ ). Nilai rata-rata hasil pengukuran parameter kualitas air secara insitu disajikan pada tabel 1 berikut.

Kisaran rata-rata salinitas pada saat pengambilan sampel adalah 31,96-33,23\% \% . Nilai salinitas yang diperoleh pada saat pengambilan sampel masih dalam batas normal untuk kondisi perairan laut $(30-40$
$\%$ (Efendie, 2000). Nilai pH hasil pengukuran relatif stabil dan masih dalam kisaran baku mutu yang diperbolehkan. Kondisi pH (derajat keasaman) pada suatu perairan merupakan faktor penentu produktivitas perairan dan mempengaruhi biota perairan baik secara langsung maupun tidak langsung. Hasil pengukuran DO di lokasi kemunculan hiu paus di Teluk Tomini berkisar antara 6,02-7,48 $\mathrm{mg} / \mathrm{l}$. Oksigen terlarut merupakan salah satu faktor penunjang kehidupan dilaut dan merupakan salah satu indikator kesuburan perairan.

Tabel 1. Nilai kisaran parameter kualitas air di lokasi kemunculan hiu paus.

Table 1. Range of water quality parameters value in the whale sharks occurrences

\begin{tabular}{|c|c|c|c|c|c|}
\hline \multirow[b]{2}{*}{$\begin{array}{c}\text { Waktu } \\
\text { Pengukuran }\end{array}$} & \multirow[b]{2}{*}{ Kedalaman } & \multicolumn{4}{|c|}{ Parameter kualitas air } \\
\hline & & $\begin{array}{c}\text { Suhu } \\
\text { (temperature) } \\
\left({ }^{0} \mathrm{C}\right)\end{array}$ & $\begin{array}{c}\text { Salinitas } \\
(\text { salinity })(\% / 00)\end{array}$ & $\mathrm{pH}$ (unit) & $\begin{array}{c}\mathrm{DO}(\text { dissolved } \\
\text { oxygen })(\mathrm{mg} / \mathrm{L})\end{array}$ \\
\hline \multirow{3}{*}{ April } & $0 \mathrm{~m}$ & $30,3-30,8$ & $33,18-33,23$ & $8-8,06$ & $6,18-6,52$ \\
\hline & $4 \mathrm{~m}$ & 30,8 & $33,15-33,23$ & $8,01-8,05$ & $6,02-7,07$ \\
\hline & $8 \mathrm{~m}$ & 30,8 & $33,18-33,23$ & $8,01-8,05$ & $6-7,4$ \\
\hline \multirow[b]{2}{*}{ Mei } & $0 \mathrm{~m}$ & $30,8-31,6$ & $31,96-34$ & - & $6-7,25$ \\
\hline & $4 \mathrm{~m}$ & $30,6-30,9$ & $32,31-32,56$ & $8,09-8,29$ & $6,05-7,4$ \\
\hline $\begin{array}{l}\text { Baku Mutu } \\
\text { (KMNLH, } \\
2014)\end{array}$ & $8 \mathrm{~m}$ & $\begin{array}{l}30,5-30,8 \\
26-32{ }^{0} \mathrm{C}\end{array}$ & $\begin{array}{c}32,35-32,55 \\
7-32 \%\end{array}$ & $\begin{array}{c}8,16-8,29 \\
7-8,5\end{array}$ & $\begin{array}{c}6,4-7,48 \\
>5 \mathrm{mg} / \mathrm{L}\end{array}$ \\
\hline
\end{tabular}

Kelimpahan plankton (fitoplankton dan zooplankton) di sekitar lokasi penelitian disajikan pada Gambar 4 dan 5. Teridentifikasi tiga kelas fitoplankton yaitu
Bacillariophyceae (13 genus), Dinophyceae (7 genus) dan Cyanophyceae (1 genus). Kelimpahan fitoplankton pada pengambilan bulan Mei lebih tinggi dibandingkan pada saat 
pengambilan bulan April. Hal tersebut diduga karena ada pergeseran lokasi pengambilan sampel, pada bulan April pengambilan sampel plankton dilakukan tepat dilokasi kemunculan

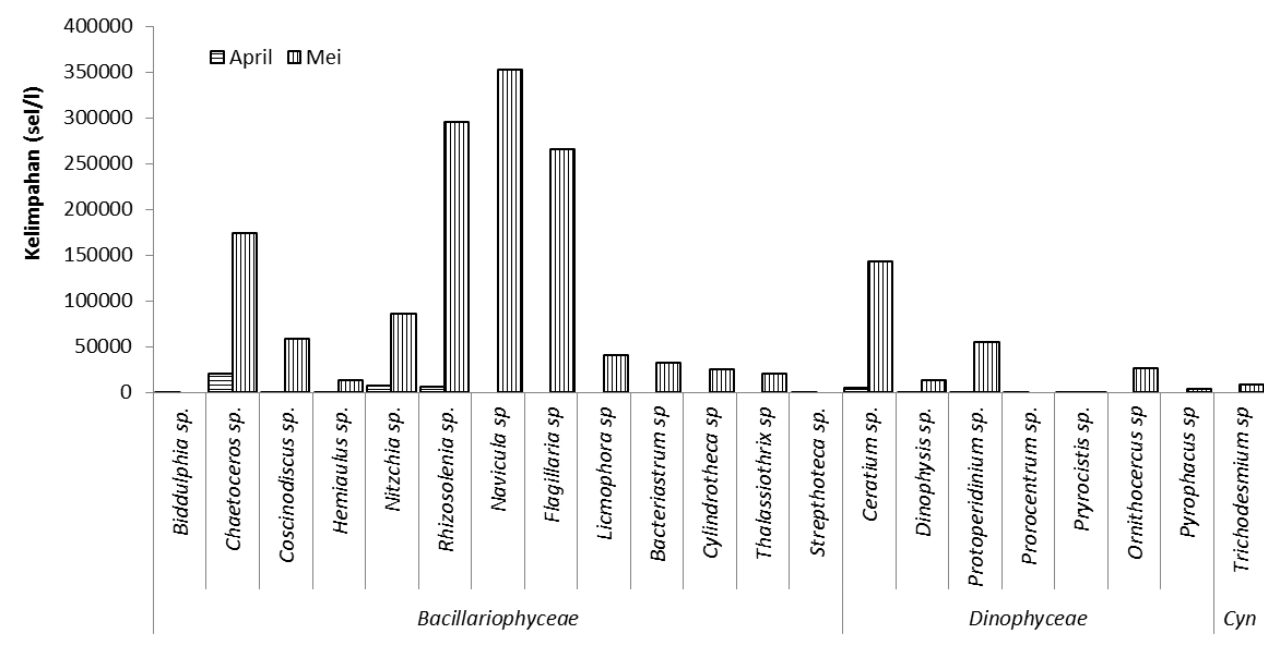

Gambar 4. Kelimpahan fitoplankton disekitar lokasi penelitian

Figure 4. Abundance of phytoplankton around the research location

Zooplankton yang teridentifikasi pada saat pengambilan sampel terdiri dari sembilan kelas yaitu: Crustaceae (sepuluh genus), Cilliata (empat genus), Hydrozoa (satu genus), Holothuroidea (lima genus), Mollusca (dua genus), Rotatoria (genus genus), hiu paus sedangkan pada pengambilan sampel bulan Mei pengambilan sampel agak bergeser keluar disekitar lokasi kemunculan hiu paus $( \pm 100 \mathrm{~m})$.

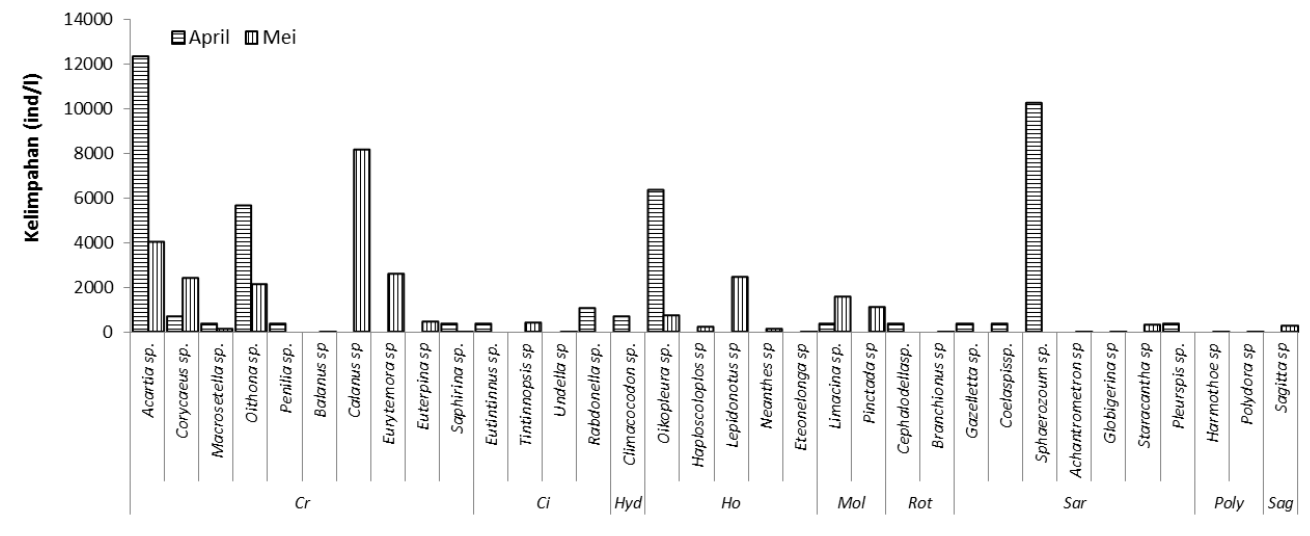

Gambar 5. Kelimpahan zooplankton disekitar lokasi penelitian

Figure 5. Abundance of zooplankton around the research location

Kelimpahan larva pada suatu perairan akan sangat ditentukan oleh ketersediaan makanan yaitu berupa plankton. Dalam siklus rantai makanan di laut, diketahui bahwa larva memanfaatkan plankton sebagai makanannya. Pengambilan sampel larva hanya dilakukan pada bulan Mei, karena pada saat survey pada
Sarcodina (tujuh genus), Polychaeta (dua genus), Sagittoidea (satu genus). Pada bulan April, Acartia sp dari kelas Crustaceae dan Sphaerozoum sp dari kelas Sarcodina memiliki kelimpahan tertinggi yaitu 12385 ind/l dan 10262 ind/l. bulan April, ada larangan perahu bermotor untuk mendekati lokasi kemunculan hiu paus. Kelimpahan larva di sekitar lokasi kemunculan hiu paus disajikan pada Gambar 6. Copepoda dan larva ikan memiliki kelimpahan tertinggi di setiap lokasi pengambilan sampel. 


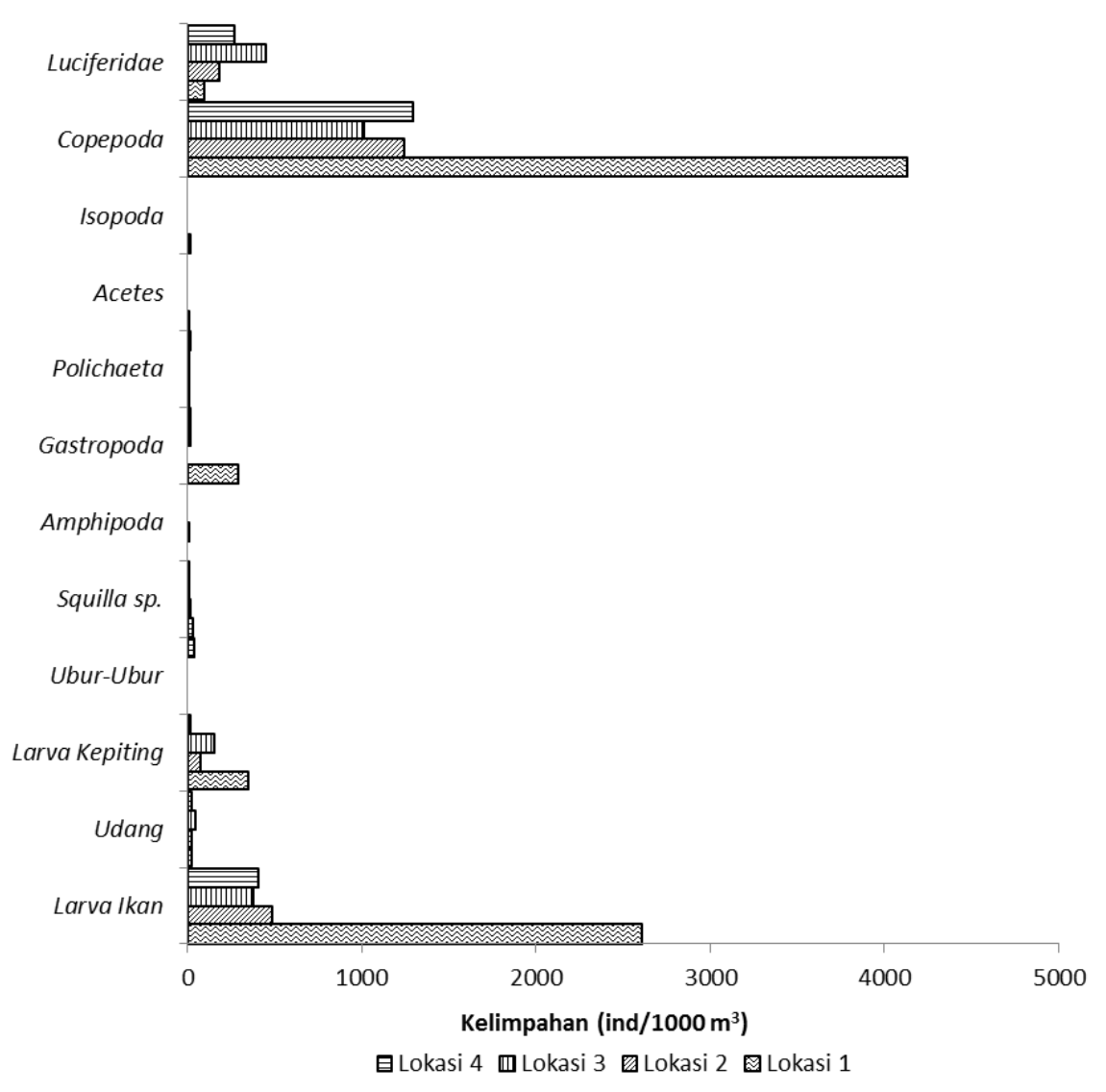

Gambar 6. Kelimpahan larva disekitar lokasi penelitian

Figure 6. Abundance of larvae around the research location

\section{Pembahasan}

Hiu paus (Rhincodon typus) cenderung bersifat kosmopolitan dan sebarannya meliputi perairan tropis dan sub tropis hangat pada suhu antara $18-30^{\circ} \mathrm{C}($ Colman, 1997) dan salinitas berkisar 34-34,5\% \%ondisi perairan tersebut diduga merupakan kondisi yang optimal untuk pertumbuhan plankton dan nekton berukuran kecil yang merupakan makanan hiu-paus. Hasil pengukuran suhu permukaan secara langsung di lokasi penelitian, berkisar antara $30,3-31,6{ }^{\circ} \mathrm{C}$ dan salinitas berkisar antara 31,69-33,23\% \% . Dengan kondisi perairan yang sesuai untuk kehidupannya, memungkinkan hiu paus dapat mendiami lokasi tersebut untuk beberapa waktu.

Hasil pengamatan bawah air, tingkah laku hiu paus yang teramati di lokasi penelitian, hiu paus muncul dari kedalaman menuju perairan yang dangkal \pm 10 meter kemudian berputarputar dan sesekali membuka mulutnya untuk mendapatkan makanan berupa plankton dengan cara menyaring air yang masuk kedalam mulutnya. Berdasarkan hasil penelitian yang dilakukan di Bahía de Los Angeles, Baja California Norte, Mexico, sekitar $80 \%$ hiu paus yang ditemukan melakukan kegiatan makan pada kedalaman $\leq 10 \mathrm{~m}(7,0 \pm 5,5 \mathrm{~m})$ (Nelson, J.D. dan Eckert, S.A., 2007). Hal tersebut kemungkinan berhubungan dengan kelimpahan plankton yang tinggi pada kedalaman antara $0-10 \mathrm{~m}$ dimana cahaya matahari masih bisa menembus sampai kedalam tersebut dan proses fotosintesis masih bisa terjadi.

Pengamatan komposisi makanan dari hiu paus hanya terbatas pada hasil observasi dan analisis isi perut dari hiu paus yang tertangkap oleh nelayan dan hiu paus yang terdampar (Silas, 1986). Jenis makanan hiu paus yang terdokumentasi dari beberapa literatur berupa spesies planktonik seperti: copepod, udang udangan dan larva kepiting, dan spesies nektonik seperti sardines, anchovies, tuna kecil, albacore dan squid (Compagno, 1984; 
Last dan Stevens, 1994). Hasil observasi di Australia bagian barat disepanjang Ningaloo Reef, hiu paus memakan tropical krill (Pseudeuphausia latifrons) dalam jumlah yang banyak (Wilson et al., 2001) sedangkan di Teluk California memakan copepod (Acartia clause) (Clark dan Nelson, 1997). Hasil analisis plankton di lokasi kemunculan hiu paus di Teluk Tomini, jenis zooplankton yang melimpah diantaranya: Acartia sp, Oithona sp, Calanus sp, Oikopleura sp dan Sphaerozoum sp.

Kejadian kemunculan hiu paus disekitar Teluk Tomini untuk saat ini belum bisa diprediksi secara tepat. Dengan penelitian yang kontinyu mengenai waktu kemunculuan hiu paus dan kondisi lingkungan di lokasi kemunculan hiu paus diharapkan kedepannya kemunculan hiu paus di Teluk Tomini dapat diprediksi. Hasil sementara perbandingan kondisi lingkungan lokasi kemunculan hiu paus di Teluk Tomini dan beberapa lokasi kemunculan lainnya mengindikasikan adanya persamaan kondisi lingkungan yang dapat menyebabkan kemunculan hiu paus tersebut di Teluk Tomini.

\section{Simpulan}

Hasil kajian beberapa parameter kualitas air dan perbandingan dengan kondisi lingkungan di beberapa lokasi kemunculan hiu paus, kondisi lingkungan Teluk Tomini mendukung untuk kemunculan hiu paus. Faktor makanan diduga kuat menjadi penarik untuk hiu paus mendatangi lokasi tersebut. Sementara itu, makanan hiu paus yang berupa organisme planktonik (fitoplankton dan zooplankton) serta nektonik (ikan yang berukuran kecil) sangat bergantung pada kondisi perairan untuk dapat berkembang secara optimal. Diperlukan kajian lebih mendalam mengenai kemunculan dan perilaku hiu paus dalam jangka waktu yang lama dan berkesinambungan di lokasi kemunculannya untuk mendapatkan data dan informasi yang akurat.

\section{Daftar Pustaka}

APHA (American Public Health Association). 2005. Standard Methods for The Examination of Water and Waste Water. $21^{\text {th }}$ ed. APHA. Washington DC. $1193 \mathrm{p}$.
Clark, E., Nelson, D.R. 1997. Young whale sharks, Rhincodon typus, feed- ing on a copepod bloom near La Paz, Mexico. Environ. Biol. Fishes 50, 63-73.

Colman, J.G. 1997. A review of the biology and ecology of the whale shark. Journal of Fish Biology 51:1219-1234.

Compagno, L.J.V. 1984. FAO Species Catalogue, vol. 4. Sharks of the world. An annotated and illustrated catalogue of shark species known to date. Part 1. Hexanchiformes to lamniformes. FAO Fish. Synopsis 125, 209-211.

Venegas R, Hueter R, Gonzalez Cano J, Tyminski J, GregorioRemolina J. (2011) An unprecedented aggregation of whale sharks, Rhincodon typus, in Mexican Coastal Waters of the Caribbean Sea. Plos One 6(4):e18994.

Duffy, C.A.J. 2002. Distribution, seasonality, lengths, and feeding behaviour of whale sharks (Rhincodon typus) observed in New Zealand waters. N. Z. J. Marine and Freshwater Reserch. 36, 565-570.

Effendie, M.I. 2002. Biologi Perikanan. Yayasan Pustaka Nusatama, Yogyakarta. 163p.

Heyman, W.D., Graham, R.T., Kjerfve, B., Johannes, R.E. 2001. Whale shark Rhincodon typus aggregate to feed in fish spawn in Belize. Marine Ecology Progress Series. 215, 275-282.

Last, P.R., Stevens, J.D. 1994. Sharks and Rays of Australia. CSIRO, Melbourne

Nelson, Jonathan D, and Scott A Eckert. 2007. Foraging Ecology of Whale Sharks (Rhincodon typus) within Bah ' Ia de Los Angeles, Baja California Norte, Mexico. Fisheries Research 84: 47-64.

Rowat D, Gore M. 2007. Regional scale horizontal and local scale vertical movements of whale sharks in the Indian Ocean off Seychelles. Fisheries Research 84: 32-40.

SEAFDEC, South East Asia Fisheries Department. 2006. The regional training workshop on larval fish identification and fish early life history science.

Silas, E.G. 1986. The whale shark (Rhiniodon typus Smith) in Indian coastal waters: is the species endangered or vulnerable. Marine Fisheries Information Service. $66: 1-19$. 
Stewart, B.S. 2012. Whale Shark Research Expedition to Teluk Cenderawasih National Park, West Papua \& Papua, Indonesia 9 - 18 June 2012. World Wildlife Fund Indonesia \& Conservation International. Hubbs-SeaWorld Research Institute 2595 Ingraham Street San Diego, CA 92109. 15 July 2012 HSWRI Technical Report 2012-379.

Tania, C. 2014. Pemantauan dan Studi Hiu Paus di Taman Nasional Teluk Cenderawasih. Laporan Pemantauan dan Studi Tahunan 2011-2013. Wasior.
Taylor, G. 1994. Whale Sharks, the Giants of Ningaloo Reef. Angus and Robertson, Sydney, $174 \mathrm{pp}$.

Wilson, S.G., Pauly, T., Meekan, M.G. 2001. Daytime surface swarming by Pseudeuphausia latifrons (Crustacea, Euphausiacea) off Ningaloo Reef, Western Australia. Bulletin Marine Science. $68:$ 157-162.

Yamaji, I. 1979. Ilustration of the Marine Plankton of Japan. Hoikusha Publishing Co. Osaka Japan. 